\title{
Literature and Science in Nineteenth-century Realist Novels: A Book Review Article about Ambrière's and Bender's Work
}

\author{
Anne-Marie Reboul \\ Complutense University Madrid
}

Follow this and additional works at: https://docs.lib.purdue.edu/clcweb

Part of the Comparative Literature Commons, European Languages and Societies Commons, Modern Literature Commons, Other Arts and Humanities Commons, and the Rhetoric and Composition Commons

Dedicated to the dissemination of scholarly and professional information, Purdue University Press selects, develops, and distributes quality resources in several key subject areas for which its parent university is famous, including business, technology, health, veterinary medicine, and other selected disciplines in the humanities and sciences.

CLCWeb: Comparative Literature and Culture, the peer-reviewed, full-text, and open-access learned journal in the humanities and social sciences, publishes new scholarship following tenets of the discipline of comparative literature and the field of cultural studies designated as "comparative cultural studies." Publications in the journal are indexed in the Annual Bibliography of English Language and Literature (Chadwyck-Healey), the Arts and Humanities Citation Index (Thomson Reuters ISI), the Humanities Index (Wilson), Humanities International Complete (EBSCO), the International Bibliography of the Modern Language Association of America, and Scopus (Elsevier). The journal is affiliated with the Purdue University Press monograph series of Books in Comparative Cultural Studies. Contact: <clcweb@purdue.edu>

\section{Recommended Citation}

Reboul, Anne-Marie. "Literature and Science in Nineteenth-century Realist Novels: A Book Review Article about Ambrière's and Bender's Work." CLCWeb: Comparative Literature and Culture 16.3 (2014): <https://doi.org/10.7771/ 1481-4374.2206>

This text has been double-blind peer reviewed by $2+1$ experts in the field.

The above text, published by Purdue University Press @Purdue University, has been downloaded 933 times as of $11 /$ $07 / 19$.

This document has been made available through Purdue e-Pubs, a service of the Purdue University Libraries. Please contact epubs@purdue.edu for additional information.

This is an Open Access journal. This means that it uses a funding model that does not charge readers or their institutions for access. Readers may freely read, download, copy, distribute, print, search, or link to the full texts of articles. This journal is covered under the CC BY-NC-ND license. 


\section{PURDUE}

UNIVERSITY PRESS <http://www.thepress.purdue.edu>

\section{CLCWeb: Comparative Literature and Culture}

ISSN 1481-4374 <http://docs.lib.purdue.edu/clcweb> Purdue University Press @Purdue University

CLCWeb: Comparative Literature and Culture, the peer-reviewed, full-text, and open-access learned journal in the humanities and social sciences, publishes new scholarship following tenets of the discipline of comparative literature and the field of cultural studies designated as "comparative cultural studies." In addition to the publication of articles, the journal publishes review articles of scholarly books and publishes research material in its Library Series. Publications in the journal are indexed in the Annual Bibliography of English Language and Literature (Chadwyck-Healey), the Arts and Humanities Citation Index (Thomson Reuters ISI), the Humanities Index (Wilson), Humanities International Complete (EBSCO), the International Bibliography of the Modern Language Association of America, and Scopus (Elsevier). The journal is affiliated with the Purdue University Press monograph series of Books in Comparative Cultural Studies. Contact: <clcweb@purdue.edu>

\section{Volume 16 Issue 3 (September 2014) Book Review Article 13}

\section{Anne-Marie Reboul,}

"Literature and Science in Nineteenth-century Realist Novels:

A Book Review Article about Ambrière's and Bender's Work" $<$ http://docs.lib.purdue.edu/clcweb/vol16/iss3/13>

Contents of CLCWeb: Comparative Literature and Culture 16.3 (2014) Including Thematic Cluster Love, Sexualities, and Marriage in Literature <http://docs.lib.purdue.edu/clcweb/vol16/iss3/> 


\title{
Anne-Marie REBOUL
}

\section{Literature and Science in Nineteenth-century Realist Novels: A Book Review Article about Ambrière's and Bender's Work}

\author{
Translated from the Spanish by Alejandro Coiradas
}

In the nineteenth century discoveries in medicine and in the natural sciences altogether awoke a fascination worldwide with its corollary, the "progress of humanity." The first two world expositions in the West held in London in 1851 and Paris in 1855 evidence the rapid development. Although there were some discordant voices such as that by Baudelaire who rejected the idea of indefinite progress in his "Exposition universelle de 1855," scientific works became popular. The greats of the natural sciences from Darwin to Pasteur contributed to the emancipation and improvement of society in the view of most, so that few writers remained aloof from this general movement and the commitment to the sciences applied to the description of "real" things and the life. In France, the influence of science on literature was considerable in the nineteenth century ranging from Stendhal and his fascination with mathematics to Zola, who based much in his oeuvre on scientific novelties by creating his "experimental novel" to Balzac, who analyzed the society by drawing on "zoological species." It is in this context that I review Madeleine Ambrière 1968 Balzac et la Recherche de I'Absolu which was republished to much acclaim in 1999 and Niklas Bender's 2010 La Lutte des paradigmes. La littérature entre histoire, biologie et médecine (Flaubert, Zola, Fontane).

Bender taught Romance literatures at the University of Tübingen and teaches as of 2014 at the University of Koblenz-Landau. He received his doctorate in comparative literature, philosophy, and German literature at the Freie University Berlin in 2007. Bender is interested in the relations between literature and knowledge. In addition, he works as a literary critic for the Frankfurter Allgemeine Zeitung. Bender argues that relations literature maintains with scientific knowledge of its age and, more precisely, with biological and medical knowledge and this is the focus of his $L a$ Lutte des paradigmes. Bender differentiates between two areas, namely life sciences (biology and medicine) on the one hand, and history on the other. Bender argues that biological and medical conceptions are determined by laws of nature while in history focus is on the cultural notion of humanity with the underlying conviction that humanity holds the clues of future. From the end of the eighteenth century and owing to the events of the French Revolution, humanity has been exercising this historical conception. Nevertheless, whereas the nineteenth century unfolded in innovations in the sciences, human knowledge and its processes acquired determinism. Therefore, two antagonistic ways of apprehension are defined almost in parallel fashion whereby theoretical and epistemological models are differentiated ideologically. He asks whether the human being is a social and cultural being integrated in history and evolving according to its own laws or is humankind determined by nature and biology. Bender's hypothesis is that these two contradictory views coexist in nineteenth-century literary texts. These two definitions of humankind developed from differentiated scientific and philosophical fields head towards a certain confrontation or conflictive relation: they are reproduced and interpreted in literary works despite their problematic relation. Bender posits that it is essential to observe how these conceptual aporeias are resolved.

It is not, therefore, the relevant extra-literary sources (whether historical or scientific) what Bender pursues in the texts, but the combined influence of systems as "paradigms" (systems thinking is relevant to the study of literature and there are several approaches by a number of scholars; for a brief description of the field see, e.g., Tötösy de Zepetnek and Vasvári). Bender's approach is to inquire how scientific discoveries are articulated with historical knowledge in nineteenth-century fiction. He does not pretend every text can be explained by following his approach, but he detects the presence in literary texts of historical and cultural points on the one hand and biomedical points of views on the other. Bender presents three chapters related to each one of Flaubert, Zola, and Fontane. He finds that the interconnection of culture/history and science is most perceptible in the work of Flaubert and Zola and that it is ethereal in the work of Fontane. Bender follows the paradigm of realism both medical and historical in a detailed and precise manner. In the case of Zola he summarizes his theory of the roman experimental and analyzes how the novelist adapts his theory in practice. With regard to the work of Fontane, Bender recognizes that the influence of science and the concept of history are not narrated explicitly, but in a "distance" and that this distinguishes Fontane from realism and naturalism in French-language literature. Hence he adopts the designation of politischer Realismus which is more impermeable to the influence and progress of science in the nineteenth century. The indirect objective in Bender's book 
consists of providing a clear "image" of the different realisms throughout the nineteenth century. Bender proposes three realisms: Romantic realism, objective realism, and scientific realism and his idea is based on Francisco Javier Prado Biezma's thought. The interest of this theory beyond the time axis and the authors is that it allows to classify the works in accordance with the three criteria linked 1) to the concept of hero, 2) to the greater or lesser presence of philosophical and scientific systems, and 3) to the development of metaphorical writing. Under this classification, Zola's writing would be part of the third group while Fontane's novels would correspond to the first group of realism.

Bender's study of Flaubert's novels is with regard to Salammbô and L'Education sentimentale and he posits that previous to Salammbô there is no similar narration either in Zola's or Fontane's novels. Further, Bender argues that the narrative perspective in Flaubert's work is complex as it answers different approaches: on the one hand, the historical knowledge of the age and on the other the impartiality of the author that removes every reference to moral or mythological perspective. While the exotic is emphasized in Salammbô, Flaubert narrates his protagonists and their actions following scientific discourses in medicine and thus Bender observes how Flaubert establishes a hierarchy: Hannon, who represents ancient psychology suffers from an exotic illness (elephantiasis), and Salammbô combines a double perspective, ancient and modern at the same time, and suffers from hysteria, defined in clinical terms, but integrated in a mythological thought which differentiates her considerably from Emma Bovary (on Bovary's sexuality see, e.g., Rooks $<$ http://docs.lib.purdue.edu/clcweb/vol16/iss3/8>; on women's suicide and mental illness in novels, see Dermitzakis <http://dx.doi.org/10.7771/1481-4374.1035>). Meanwhile, the Mercenaries are characters treated from a modernist perspective based on Jean-Baptiste-Henri Savigny's thesis in Wreck of the Medusa. In the description of their suffering and death, under the effects of hunger and thirst, Flaubert brings out the eternal truths of the body and reaches anthropological dimensions. Bender's analysis is extensive and very interesting and enables us to observe the resolution of the conflict regarding one trilogy: three exemplary protagonists (Hanoon, Salammbô, and the Mercenaries) who respond to three pathologies (on this, see also Reboul Díaz, "Saint-Julien").

Bender follows in Flaubert's novel all mythological, historical, and medical sources. His explanations are in particular interesting because discusses the misunderstandings which met Flaubert's work in his time. With Salammbô, Flaubert did not present a historical novel similar to the novels of Walter Scott or Alexandre Dumas. Instead, he narrated a "poetic history" with which he called into question the philosophy of nineteenth-century History and criticized its theological conception. In L'Education sentimentale Flaubert invoked the 1848 revolution and in Bender's opinion the historical context dilutes the text's coherence and logic when the narrative is mostly about the individual and society. Further, Bender posits that Flaubert did not take advantage to construct a description of the historical events of 1848 and referred instead to crises of opinion and to the discrediting of political speeches. Further, in L'Education sentimentale biomedical knowledge is less developed and narrated than in Salammbô.

In his chapter two Bender analyzes Zola's Nana and Germinal and discusses Zola's theory of realism in his 1880 Le Roman expérimental by observing the influences on Zola by biological thought. While in my opinion this is less interesting because it has been discussed previously (see, e.g., Pagès), more relevant is Bender's analysis of biological and natural heritage on the one hand, and society and the concept of history on the other. For example, Nana's story is narrated by making her an emblematic figure of the Second Empire and thus Flaubert constructed the historical depth of the novel. With her, sexuality against social norms, misery, and alcoholism Nana turns into a toxic ferment of society and in Flaubert's complex metaphorical narration the "virus" of Nana becomes a useful ferment as it accelerates the fall of a disastrous political regime. Thus the metaphor of ferment while it functions according to biology, in Zola's narration turn into positive tools. By mediation of an own logic of organic life, justice is fulfilled and Zola manages to fuse his two models together, namely nature and history. In Germinal, Zola mobilized in many occasions his expertise in the medical sciences because of the several pathologies that life generates inside the mine. In the same way and owing to the presence of the political, the economy, and social conflict, the novel is about specific historical processes.

The ground is prepared for this conflict between the two epistemological models, one lineal and related to the idea of the growth, progress, and emancipation and another circular derived from the natural and biological model. In this case, Bender pays attention to metaphoric and symbolic networks generated in and by the political speeches (the socio-political writing opposes the hell of the mine against the artificial paradise of the surface), as well as descriptions of the mine 
personified in a homicidal and cannibalistic monster. Bender also discusses internal contradictions in the novel: the right order is reached by the intervention of natural ways and it is the exploitation of model of nature what allows Zola to illustrate the social events and the positive lineal historical process that reduces the possibilities of progress. In the end, internal contradictions multiply themselves as criticism of the Second Empire and that of modernity happen to be the same.

Bender offers a general vision of the cycle in Les Rougon-Macquart while bringing out the fact that a second-level conflict related to the physiological nature always throbs in an underlying way even in novels of major social and political issues. Humankind is not a being freed from its acts and awareness has little influence in the course of the story. According to Bender, Zola tried to bring together the forces of nature with the ideas of culture. At the same time, this synthesis allowed Zola to develop a peculiar narrative dynamic with multiple and contradictory forces which concede to determinant factors such as heritage, sexuality, hunger, etc. The needs of determinism ally with the proper dynamic found in history and its arbitrariness and ambiguity. Bender argues that these paradoxes do not diminish the narrative force of Zola's novels although they take away some of their enchanting qualities in second and third readings. Bender even considers "kitsch" when discussing Zola's texts $(374,379)$.

In his last chapter Bender analyzes Fontane's Effi Briest and Irrugen, Wirrungen based on two theoretical paradigms he defines in his book. In Effi Briest Fontane described a social conservative order and reactionary Prussian rural society. Fontane's novels specify neither natural forces nor biological ones; however, the Bender perceives in a deeper structural level some aspects which compromise the apparent harmony. At the level of nature, Fontane introduced disease, suffering, and death, but the pathological descriptions are always discreet. He excluded any discordant element, but ghosts and the supernatural take over with a noticeable presence of the irrational and the fantastic in the everyday world. Fontane provided an aesthetic solution, but he also leaves a worrying, transgressive potential in his work about transgressions of society's rules. Fontane had a preference for allusion and thus human life led by nature is omnipresent in his novels by narrating symbolic networks. Fontane's portrayed world is not proposed as a model: it is accepted only with resignation with an impact on the search for personal happiness that, according to circumstances, is found in aesthetic contemplation or in the recourse to phantoms. In Irrugen, Wirrungen the historical model is repeated, as well as the stylistic characteristics found in Effi Briest. Fontane concentrated on social conventionalism against emotion and reason, but at the same time and in a latent way, transgression and desire become primary motives. Under an idealistic representation of society, another reality and another model are perceived although at the end resignation, abnegation, and the effort of not infringing upon social rules and avoiding conflict dominate. As in Effi Briest, there is no true adhesion to historical reality, but the emotional worlds of individuals are foregrounded by the narration of manifest acts of resignation and self-mutilation.

My comparison between Bender's and Ambrière's is based on the fact that they work with a similar approach with regard to relations between science and literature. However, they differ in methodology. Ambrière analyzes Balzac's 1834 Balthazar Claës ou la recherce de l'absolu in which the protagonist dedicates himself to science. Ambrière's study is extensive as she studied all information related to the text from the conception of the subject to corrections by Balzac for a later publication, etc. Ambrière is professor emerita at the Sorbonne. She is a specialist in nineteenthcentury literature and in particular of Balzac's work. Relevant is that both Ambrière and Bender study novels written in French which are narrations of science in literature. However, while Ambrière's work is based on literary history and sources, Bender's workis based on philology and textual criticism. Ambrière proposes an exhaustive study of the whole information the novelist had at hand, every consulted source, all the texts the novelist read and even records of simple friendly encounters. For example, Ambrière consulted sources about Balzac's encounters with scholars whose specialty was chemistry so that his description would correspond to facts of science.

According to Ambrière, Balthazar Claës was inspired in Jöns Jacob Berzélius's 1831 Traité de chimie in which Balzac read about the division in organic and inorganic chemistry, the phenomenon of crystallization, the nature of metals, etc. Balzac extracted precise chemical processes such as those of sugar, Arabic gum, and starch or the decomposition of the nitrogen an important dramatic part in the novel (see Ambrière 320-34; see also Schummer, Bensaude-Vincent, Van Tiggelen). Owing to Balzac's eagerness of bringing to his text Lavoisier's knowledge of chemistry - and whom the protagonist Claës declares to be a disciple of - we can put a name behind the novel's hero. Further examples include the decomposition of tears (Balzac's source is Fourcroy and Vauquelin, two chemists who published in 1791 a text about the subject [see Ambrière 399-417]), 
and the manufacturing of diamonds. Ambrière reconstructs the novel's scientific and chemical view without disregarding journalistic sources based on Balzac's and Jean-Baptiste Dumas's - a member of the French Academy of Sciences - correspondence (see Balzac, Correspondance) and she presents a detailed description of Balzac's knowledge of science. However, Ambrière does not limit herself to the detailed analysis of the scientific documents consulted by Balzac and she analyses also the result of the effort for inserting any of those documents in the literary text. Following Raymond Debray-Genette's work on Flaubert (whose study Bender did not consult), she identifies the transfigurations brought to the original text of Balzac and detects alterations and omissions with regard to science in Balzac's novel. While Balzac's imagination modified perceptions about science, Ambrière's view is that although Balzac respected science and used available information, he did not buy into the then current enthusiasm about science and its privileged position for the betterment of humankind.

In conclusion, while Bender does not present discussions about the knowledge of science itself, Ambrière excels in sourcing science in order to reveal the archeology of Balzac's novels. Bender stresses the fundamental structures of the novels he is analyzing and the most relevant matter of his study is found in literary analysis from a narrative and thematic point of view. Nineteenthcentury French realist writers did not restrict themselves to using science in their fiction and in combination with the narration of fiction their writing is complex. I posit that said complexity in addition to the style and content of their narration is linked to the incorporation of other arts such as painting and opera. At the same time, this strategy did not always work. For example, Balzac was not successful in making Rossini's opera "heard" in his short novel Massimila Doni and wrote that "one must study music just like I studied chemistry for the writing of La Recherche de I'Absolu" ("il faut étudier la musique, comme j'ai étudié la chimie pour écrire La Recherche de I'Absolu" (Correspondance 3, 286; see also Ambrière 293; Reboul Díaz, "Mosé in Egitto"). Thus, in French realist novels of the nineteenth century the use and incorporation of extra-literary matter, particularly science, was an important part of writing fiction as the studies by Ambrière and Bender demonstrate and thus their studies represent important scholarship.

\section{Works Cited}

Ambrière, Madeleine. Balzac et la recherche de l'absolu. 1968. Paris: Hachette, 1999.

Balzac, Honoré. Correspondance. Ed. Roger Pierrot. Paris: Garnier, 1960-1968. 5 vols.

Balzac, Honoré. Balthazar Claës ou la recherce de l'absolu. Paris: Mme Charles-Béchet, 1834.

Baudelaire, Charles. "Exposition Universelle 1855." Oeuvres Complètes. By Charles Baudelaire. Paris: Gallimard, 1976. Vol. 2, 575-83.

Bender, Niklas. La Lutte des paradigmes. La littérature entre histoire, biologie et médecine (Flaubert, Zola, Fontane). Amsterdam: Rodopi, 2010.

Berzélius, Jöns Jacob. Traité de chimie. Trans. A.J.L. Jourdan. Paris: Firmint-Didot frères, 1816-1835. 8 vols. Debray-Genette, Raymonde. Métamorphoses du récit. Autour de Flaubert. Paris: Seuil, 1988.

Dermitzakis, Babis. "Some Observations about the Suicide of the Adulteress in the Modern Novel." CLCWeb: Comparative Literature and Culture 1.2 (1999): <http://dx.doi.org/10.7771/1481-4374.1035>.

Pagès, Alain. "En partant de la théorie du roman expérimental." Les Cahiers naturalistes 47 (1974): 70-87.

Prado Biezma, Francisco Javier. La Novela francesa. Madrid: Planeta, 1982.

Reboul Díaz, Anne-Marie. "Mosé in Egitto de Rossini et Sainte Cécile de Raphaël dans la nouvelle musicale et poétique de Balzac, Massimila Don." Palabra y Música. Ed. Anne-Marie Reboul Díaz. Madrid: Complutense U Madrid, 2005. 339-60.

Reboul Díaz, Anne-Marie. "Saint-Julien I'Hospitalier. La otra vidriera." Revista de Filología Francesa 5 (1994): 147-59.

Rooks, Amanda Kane. "Motherhood and Sexuality in Flaubert's Madame Bovary." CLCWeb: Comparative Literature and Culture 16.3 (2014): <http://docs.lib.purdue.edu/clcweb/vol16/iss3/8>

Schummer, Joachim, Bernadette Bensaude-Vincent, and Brigitte van Tiggelen, eds. The Public Image of Chemistry. Singapore: World Scientific Publishing, 2007.

Tötösy de Zepetnek, Steven, and Louise O. Vasvári. "About the Contextual Study of Literature and Culture Globalization, and Digital Humanities." Companion to Comparative Literature, World Literatures, and Comparative Cultural Studies. Ed. Steven Tötösy de Zepetnek and Tutun Mukherjee. New Delhi: Cambridge UP India, 2013. 3-35.

Zola, Emile. Le Roman expérimental. Paris: Charpentier, 1880. 
Reviewer's profile: Anne-Marie Reboul teaches French-language philology at Complutense University Madrid. Her interests in scholarship include in general and comparative literature literature and painting and literature and cinema. Reboul Díaz's recent publications include "La Réception critique de l'oeuvre théâtrale d'Albert Camus en Espagne," Camus de l'autre côté du mur. Réceptions de l'oeuvre camusienne (Ed. Judit Maár et Krisztina Horváth, 2014) and "Cine, ensayo y pintura. Las imágenes en la obra de Pascal Quignard," Entre escritura e imagen. Lecturas de narrativa contemporánea (Ed. Lourdes Carriedo, María Dolores Picazo, and María Luisa Guerrero, 2013). E-mail: <amreboul@ucm.es>

Translator's profile: Alexander Coiradas graduated from the Faculty of Translation and Interpretation Studies Centre Philip II Superior in 2014 specializing in Spanish, English, and French translation.

E-mail: <coiradas.herrera.alejandro@gmail.com> 